\title{
POLITTIKK
}

\section{Mannen, myten og utenrikspolitikken: Putin som utenrikspolitisk aktør}

\author{
Helge Blakkisrud \\ Norsk Utenrikspolitisk Institutt (NUPI)
}

\begin{abstract}
Sammendrag
I henhold til den russiske grunnloven tilligger utenriks- og forsvarspolitikk formelt presidentens domene. Etter at Putin nå i snart tjue år har vært med på å prege politikken, er det etter hvert vanskelig å skille mellom hva som er Putins personlige stil og påvirkning og hva som representerer grunntonen og de lengre linjer i russisk utenrikspolitikk. Men hvor står Putin ved inngangen til sin fjerde - og i henhold til grunnloven siste - presidentperiode? Hva kjennetegner ham som person og politiker? Og hva kan vi forvente fra Putin på den utenrikspolitiske arenaen i løpet av den neste seksårsperioden?
\end{abstract}

Nøkkelord: Putin • Russland • utenrikspolitikk • statsledere

Utgangspunktet for denne fokusspalten er spørsmålet om hvordan de fem nye/ nyvalgte lederne $\mathrm{i}$ de faste medlemsstatene i FNs sikkerhetsråd vil kunne påvirke dynamikken i internasjonal politikk: hvordan deres personlige stil, referanserammer, strategier og måter å operere på vil virke inn på utenrikspolitikk og internasjonale relasjoner. Men den russiske presidenten, Vladimir Putin, er ingen nykommer hverken i russisk eller internasjonal sammenheng. Når beretningen om det 21. århundre skal skrives, vil russisk historie - på godt og vondt - være knyttet til Putins navn. Putin entret den internasjonale scenen allerede høsten 1999 da en syk og aldrende Boris Jeltsin utpekte ham til sin offisielle etterfølger. Siden den gang har Putin satt sitt tydelige preg på russisk politikk. I likhet med de øvrige lederne som presenteres her, har Putin riktignok nylig vært giennom et valg; det var presidentvalg i Russland

\footnotetext{
^Kontaktinformasjon: Helge Blakkisrud, epost: hb@nupi.no

(C)2018 Helge Blakkisrud. This is an Open Access article distributed under the terms of the Creative Commons Attribution 4.0 International License (http://creativecommons.org/licenses/by/4.0/), allowing third parties to copy and redistribute the material in any medium or format and to remix, transform, and build upon the material for any purpose, even commercially, provided the original work is properly cited and states its license.

Citation: Helge Blakkisrud (2018). Mannen, myten og utenrikspolitikken: Putin som utenrikspolitisk aktør, 76: 250-258.

http://dx.doi.org/10.23865/intpol.v76.1440
} 
18. mars i år. Men dette var kun et pliktløp hvor utfallet i praksis var gitt på forhånd, og hvor Putin til slutt endte opp med $76,7 \%$ av stemmene.

I henhold til den russiske grunnloven tilligger utenriks- og forsvarspolitikk formelt presidentens domene - utenriksministeren rapporterer til presidenten, ikke statsministeren. I motsetning til Jeltsin har Putin vært genuint engasjert i utformingen av russisk utenrikspolitikk. Etter at han nå i snart tjue år har vært med på å prege politikken, er det etter hvert vanskelig å skille mellom hva som er Putins personlige stil og påvirkning og hva som representerer grunntonen og de lengre linjer i russisk utenrikspolitikk. Allerede i Putins første presidentperiode konkluderte enkelte med at "To a very large extent, Putin is Russian foreign policy» (Lo 2003: 43). Men hvor står Putin ved inngangen til sin fjerde - og i henhold til grunnloven siste - presidentperiode? Hva kjennetegner ham som person og politiker? Og hva kan vi forvente fra Putin på den utenrikspolitiske arenaen i løpet av den neste seksårsperioden?

\section{En usannsynlig leder}

At Putin skulle komme til å stå i sentrum for russisk politikk i mer enn to tiår var på ingen måte gitt. Da han ble rekruttert av Boris Jeltsin som statsminister - og etter hvert president - ble han ofte beskrevet som en litt fargeløs byråkrat med bakgrunn fra en mellomstilling i etterretningstjenesten.

Putin hadde vokst opp i enkle kår i St Petersburg. Begge foreldrene var fabrikkarbeidere, og familien bodde i en såkalt "kommunalka», en kommunal leilighet hvor hver familie fikk tildelt ett rom, men delte kjøkken og bad. Etter endte jusstudier i 1975 begynte han å jobbe for KGB, først med kontraetterretning og overvåkning av diplomater hjemme i St Petersburg, før han avanserte til en stilling i Dresden i det daværende Øst-Tyskland i 1985. I Sovjetunionens siste måneder forlot imidlertid Putin KGB og gikk inn i lokalpolitikken i St Petersburg som den liberale borgermester Anatolij Sobtsjaks høyre hånd. Her jobbet han sammen med flere personer som på 2000-tallet skulle få en fremtredende plass i rikspolitikken, inkludert nåværende statsminister Dmitrij Medvedev. Etter at Sobtsjak overraskende tapte borgermestervalget i 1996, ble Putin rekruttert til presidentadministrasjonen i Moskva, og nå tok karrieren for alvor av: I 1997 ble han nestleder av administrasjonen, i 1998 sjef for FSB (KGBs etterfølger) og i 1999 statsminister.

Ved tiltredelsen hevdet mange at Putin kun var en marionett styrt av den såkalte Jeltsin-klanen, også kjent som "familien», en samling av Jeltsins kjødelige slektninger, oligarker og toppolitikere, for å videreføre og sikre denne kretsens maktposisjon. Men de påståtte dukkeførerne - kanskje fremst den kontroversielle mediemogulen Boris Berezovskij - skulle snart oppdage at Putin hadde egne ambisjoner. Mens Berezovskij endte opp i selvpålagt eksil, bygde Putin målbevisst og møysommelig opp sitt eget team av lojale støttespillere. I løpet av sine første fire år ved makten ryddet han gradvis feltet for politiske utfordrere og potensielle alternative maktsentra. Etter dette har han fremstått som Russlands ubestridte leder (Zygar' 2016). 


\section{Helge Blakkisrud}

Helt fra første øyeblikk Putin inntok Kreml, har det blitt spekulert i hvordan bakgrunnen fra etterretningstienesten har formet hans verdenssyn (se for eksempel Dyson 2001; Hill \& Gaddy 2013). Putin var trass i det korte innhoppet som statsminister høsten 1999 fortsatt et relativt ubeskrevet blad da han tok over som fungerende president på århundrets siste dag. Spørsmålet om «Hvem er Mister Putin?» ble gjerne fulgt av karakteristikker som "enigmatic», «elusive» og «inscrutable» (Charap 2004: 55).

Atten år senere personifiserer Putin russisk politikk; grensene mellom personen og staten har tilsynelatende blitt visket ut. Ideologien - eller kanskje mer presist styringsmodellen - omtales gjerne som "putinisme». Mens enkelte, med henvisning til Putins uttalelse om at Sovjetunionens oppløsning var «det 20. århundres største geopolitiske katastrofe» (Putin 2005), fortsatt vil hevde at Putins utsyn er preget av en oppvekst i Brezjnev-epoken, da Sovjetunionen sto på høyden av sin makt (Applebaum 2012), er han er også uten tvil formet av systemet han selv har vært med på å bygge opp gjennom sine snart to tiår ved makten: Putin har allerede nå sittet lenger som president enn i noen annen stilling han har innehatt i løpet av karrieren.

Hva er hemmeligheten bak Putins suksess? Ved første øyekast kan det være vanskelig å forstå Putins appell blant russiske velgere. Han er ingen glitrende taler eller karismatisk personlighet i tradisjonell forstand. Han kan tvert imot virke tilkneppet og tvungen. Men han har truffet en nerve i den russiske befolkningen i måten han kombinerer det lave og det opphøyde, gatespråk og presidentembetets pomp og prakt. Den kjente russlandsforskeren Richard Sakwa gir følgende karakteristikk: "While not naturally a charismatic individual, Putin's persona reflect[s] not just the grandeur of the office but a distinctive mix of the demotic and the demiurge" (Sakwa 2008: 882).

Dette er kombinert med en stor grad av gjennomføringsevne. Det er selvfølgelig ikke slik som en av og til kan få inntrykk av i mediene at Putin tar alle avgjørelser i russisk politikk. Gjennom sine år ved makten har Putin alltid omgitt seg med rådgivere og medarbeidere fra ulike grupper og nettverk. Og mye politikk er rutine også i Russland. Det russiske byråkratiet, eller «sistema» (systemet) (Ledeneva 2006), tungrodd og tilsynelatende alltid ekspanderende, legger selvfølgelig begrensninger. Men når Putin først bestemmer seg, er styringskursen lagt.

Putin som person er ingen revolusjonær eller ideologisk ledestjerne, han er mer en praktiker og teknokrat som bygger stein på stein. Lederstilen har blitt betegnet som "hands on" (Sakwa 2010). Han går ikke av veien for kompromiss og kooptering - men slår også nådeløst ned på meningsmotstandere som oppfattes som en trussel. Som utenrikspolitiker er han mer opptatt av å spille på styrke og frykt fremfor å bli godt likt.

Samtidig har Putin som politisk leder vist teflonkvaliteter - ingen krise eller katastrofe har gjort nevneverdig utslag på oppslutningen. Selv om det er grunn til en viss skepsis når det gjelder meningsmålinger om lederoppslutning $\mathrm{i}$ autoritære/semi-autoritære stater (Rogov 2018), er det ingen grunn til å betvile at Putins 
lederstil har gått hjem i brede lag av den russiske befolkningen. Etter å ha toppet seg i kjølvannet av anneksjonen av Krim i 2014, da 89\% sluttet opp om Putins politikk, har han riktignok de siste månedene - til tross for et svært vellykket fotball-VM på hjemmebane sommeren 2018 - tapt noe støtte. Den viktigste årsaken til dette er problemene med å selge inn en sårt tiltrengt pensjonsreform, med bred motstand mot en gradvis innfasing av en høyere pensjonsalder for både kvinner og menn (fra dagens 55 år for kvinner og 60 for menn). Overordnet har imidlertid Putin vist imponerende slitestyrke: Etter 18 år ved makten er fortsatt $67 \%$ fornøyd med Putins politikk (Levada 2018). Et viktig grep for å pleie intern oppslutning og legitimitet, særlig etter at han vendte tilbake til Kreml i 2012, har vært utenrikspolitikken (Busygina 2018).

\section{Pragmatikeren}

Som utenrikspolitisk aktør har Putin vist seg å være en pragmatiker. Selv om ambisjonen om å gjenreise Russland som internasjonal stormakt har ligget fast fra dag én (Putin 1999), har Putin flere ganger underveis skiftet strategi, avhengig av hva han har oppfattet som mest hensiktsmessig fremgangsmåte for å nå dette målet. Gjennom sine år ved makten har Putin derfor gjennomført flere politiske hamskifter.

Hans første presidentperiode (2000-2004) var preget av strategisk vestvending på det utenrikspolitiske plan og fortsatt økonomisk reform på hjemmebane. Et ofte brukt eksempel for å illustrere førstnevnte er handlemåten i etterkant av terroranslaget mot USA 11. september 2001. Da trosset Putin sine rådgivere så vel som representanter for opposisjonspartiene i Statsdumaen og strakte ut en hånd til president George W. Bush, noe som blant annet banet vei for et langt tettere etterretningssamarbeid enn tidligere og for etablering av amerikansk militært nærvær i Sentral-Asia.

Med andre periode (2004-2008) så vi derimot en helt annen Putin. Skuffelse over hva man hadde oppnådd med samarbeidslinjen førte til at "selvhevdelse» og ivaretakelse av russiske interesser ble sentrale stikkord for Russlands forhold til omverdenen, mens liberale reformer måtte vike for statskapitalisme på hjemmebane. Da Putin i 2012 vendte tilbake til Kreml etter fire år med «tøvær» under Dmitrij Medvedev som "stedfortredende" president, tok utenrikspolitikken nok en omdreining i retning av å omdefinere Vesten fra samarbeidspartner og marked til motpart og utfordrer.

Gjennomgripende kan man imidlertid beskrive Putins tilnærming som farget av en forståelse av internasjonale relasjoner som en kamp om posisjoner og makt i form av et nullsumspill. Putin er med andre ord en pragmatisk realpolitiker. Bobo Lo har oppsummert det dominerende russiske verdenssynet som:

a Hobbesian understanding of the world as an essentially hostile and "anarchic» place; the fear of encirclement by outside forces; and a strategic culture dominated by the geopolitical triad of zero-sum calculus, the balance of power and spheres of influence (Lo 2006: 3). 


\section{Helge Blakkisrud}

\section{Taktikeren}

Putin har også utmerket seg som en dreven taktiker - han har gang på gang lyktes med å spille en (relativt) svak hånd til Russlands fordel (Walt 2015). Putin entret den utenrikspolitiske arenaen som en outsider og underdog. Mens Jeltsin i alle år i sine møter med vestlige ledere hadde kunnet trekke på rollen han hadde spilt $\mathrm{i}$ den fredelige oppløsningen av Sovjetunionen, måtte Putin bygge sin posisjon basert på Russlands sterkt reduserte kapabiliteter og tilsvarende evne til å projisere makt (Blakkisrud 2008). Men fra debuten på den internasjonale arena har han vist sin evne til å utnytte selv et begrenset handlingsrom til russisk fordel: På vei til sitt første G8-toppmøte sommeren 2000 la Putin veien om Nord-Korea, der Moskva fortsatt hadde en viss innflytelse. Her lyktes han å fremskaffe løfter fra Kim Jong Il om at nordkoreanerne ville vurdere å stanse et program for utvikling av interkontinentale raketter. Med et enkelt grep lyktes Putin dermed med å sette dagsorden på sitt første møte med lederne for verdens ledende økonomier.

Enkelte har fremhevet Putins evner som strateg (Kissinger 2014). Andre mener Putin først og fremst er en dyktig taktiker, men at hans forkjærlighet for taktiske «kupp» har ført til en prioritering av kortsiktig vinning og "stormaktsforfengelighet» (great power vanities) på bekostning av mer langsiktige målsetninger (Lo 2018: 29, se også Mankoff 2014). Dette så vi klart i forbindelse med annekteringen av Krim i 2014: Putin handlet raskt, uventet og besluttsomt. På kort sikt var gevinsten enorm: På hjemmebane var "gjeninnlemmelsen» av Krim ekstremt populær. De langsiktige konsekvensene har imidlertid vært mer diskutable: Integreringen av Krim har vist seg svært kostbar, samtidig som stadig nye runder med sanksjoner i etterkant av annekteringen og den russiske innblandingen i Øst-Ukraina har satt russisk økonomi under press. En kortsiktig gevinst har gitt en langsiktig baksmell.

Etter Krim har Putin gjort flere forsøk på å manøvrere Russland tilbake i det gode selskap. Det er for eksempel naturlig å se det russiske engasjementet i Syria i et slikt lys. Selv om Sovjetunionen/Russland har hatt et langvarig nærvær i Syria, var det neppe dette, eller hensynet til den russiske marinebasen i Tartus, som var avgjørende for beslutningen høsten 2015 om å gå inn med militær støtte til Assad-regimet. Putin ønsket derimot å posisjonere seg slik at Washington og europeiske hovedsteder igjen måtte forholde seg til Moskva. Mange var skeptiske og spådde at Russland ville kjøre seg fast i en kostbar og endeløs kampanje. Som vi vet, har utviklingen på bakken imidlertid gått i Assads - og Russlands - favør. IS er på det nærmeste slått tilbake og de USA-støttede opposisjonsstyrkene presset tilbake til noen mindre enklaver. Putins gambling i Syria har dermed gitt resultater på bakken og økt russisk innflytelse i Midtøsten, men foreløpig er det få tegn til et giennombrudd på den internasjonale arena. Tvert imot har Syria-engasjementet sannsynligvis bidratt til økt spenning i relasjon til Vesten.

Et annet eksempel på mislykket manøvrering i kjølvannet av Krim var forsøket på en splitt-og-hersk-taktikk vis-à-vis Europa: I et forsøk på å undergrave 
den europeiske sanksjonspolitikken har Kreml støttet ytre høyre og nasjonalistiske partier og politikere i ulike EU-land. Putin har helt siden han vendte tilbake til presidentembetet i 2012, profilert seg på en blanding av nasjonal retorikk og tradisjonelle, konservative ideer - som en forsvarer av det "sanne Europa», det Europa som en gang var før det falt offer for multikulturalisme og normoppløsning. Støtten til politikere som Frankrikes Marine Le Pen og Nederlands Geert Wilders har imidlertid gitt begrensede resultater. Det seneste året har riktignok flere Putin-vennlige politikere kommet i posisjon: I april 2018 ble Viktor Orbán gjenvalgt for nok en periode i Ungarn, og valgene i Østerrike (oktober 2017) og Italia (mars 2018) brakte høyrenasjonale, Putin-vennlige krefter til makten. Putins vellykkede besøk hos kansler Sebastian Kurz i juni i år, kun få uker før Østerrike overtok formannskapet i EUs ministerråd, og østerrikske og italienske oppfordringer om å myke opp sanksjonsregimet, vitner om at Putin har fått flere støttespillere i europeisk politikk.

Det virker allikevel som om Putin nå har besluttet å vende tilbake til tidligere praksis med å kultivere relasjonene til lederne av de tunge EU-landene (Moskva har alltid foretrukket den bilaterale rammen fremfor å forholde seg til et samlet EU). Med et historisk dårlig forhold til Storbritannia i kjølvannet av drapsforsøket på den russiske tidligere dobbeltagenten Sergej Skripal, og Theresa May tilsynelatende lammet av Brexit, betyr det Frankrikes Emanuel Macron og Tysklands Angela Merkel. Et eksempel på dette så vi i beslutningen om å invitere Macron som hedersgjest (sammen med Japans Shinzo Abe) på Putins økonomiske utstillingsvindu, det årlige St Petersburg International Economic Forum i mai i år. Også Merkel besøkte Russland i vår; hun møtte Putin i Sotsji for å diskutere Nord Stream 2-prosjektet, den omstridte utvidelsen av gassrørledningen gjennom Østersiøen som er ment å redusere Gazproms avhengighet av Ukraina som transittland. Dette var det første bilaterale møtet mellom de to siden Russlands anneksjon av Krim i 2014. I august i år fulgte Putin opp med gjenvisitt i Berlin.

Til tross for at Putin fortsetter å stange hodet i sanksjonsmuren - det europeiske sanksjonsregimet forlenges fortsatt rutinemessig, om enn med tiltagende protester fra enkelte av Putins støttespillere - ser det dermed ut til at Putin i det minste er i ferd med å manøvrere seg tilbake til en mer åpen dialog med Paris og Berlin.

\section{Ambisjonen om stormaktstatus}

Den ultimate målestokken for hvorvidt Russland igjen har inntatt den posisjon Putin mener er naturlig og rettmessig, er imidlertid knyttet til forholdet til USA. Dette er en del av den gamle supermaktsrefleksen. Her har Putin opplevd enkelte øyeblikk av triumf for det personlige diplomati, som da president George W. Bush uttalte at han hadde "looked the man in the eye. I found him very straightforward and trustworthy I was able to get a sense of his soul» (Stent 2015: 62). Men i det store og hele har forholdet til USA gått fra vanskelig til verre. 


\section{Helge Blakkisrud}

Etter at relasjonene til USA hadde kjørt seg fast under Obama-administrasjonen, var det store forhåpninger i Moskva til at det amerikanske presidentvalget skulle føre til en ny dynamikk i det bilaterale forholdet. Det er ingen tvil om at Putin foretrakk Donald Trump fremfor Hillary Clinton. Etter hennes mislykkede forsøk på en «reset» i 2009, frontet Clinton en stadig mer haukete linje vis-à-vis Moskva. Med Trump som en novise i utenrikspolitisk sammenheng var mulighetsrommet større - både i positiv, men også negativ retning.

Siden Trump tiltrådte har han og Putin møttes tre ganger, senest i forbindelse med et eget toppmøte i Helsinki i juli. Personkjemien mellom de to ser ut til å være god, men de konkrete resultatene har så langt, sett fra Putins side, vært skuffende. Med den rollen «Russland» har blitt tildelt i amerikansk innenrikspolitikk, er det svært begrenset hvilke initiativer Trump kan ta uten at det får innenrikspolitiske konsekvenser. Dette fikk vi klart demonstrert i kjølvannet av toppmøtet i Helsinki. Putin har derfor i svært liten grad klart å kapitalisere på maktskiftet i Washington og den relativt sett gode personlige tonen med Trump.

Trumps uttalelse i forkant av G7-møtet om at utestengelsen av Russland fra dette forumet burde oppheves, en potensielt symboltung handling som av Putin ville blitt tolket som at "straffen» for anneksjonen av Krim nå var "sonet», fikk ingen praktiske konsekvenser. Likeledes, da Trump i etterkant av det skandaleombruste toppmøtet i Helsinki annonserte at han ville invitere Putin til Det hvite hus i høst, svarte den amerikanske kongressen med en ny runde sanksjoner rettet mot russiske myndigheter. Putin innser også at det kan være risikabelt å binde seg for tett til Trump: En for helhjertet omfavnelse av Trump med sikte på kortsiktig gevinst kan fort slå tilbake på de bilaterale relasjonene etter 2020, evt. 2024.

\section{En strategisk snuoperasjon mot øst?}

Putins Russland har blitt beskrevet som en stormakt av det 20. århundre som sliter med å tilpasse seg det 21. århundres realiteter, der det klamrer seg til anakronistiske forestillinger om maktbalanse og stormaktsdiplomati (Lo 2018). I kjølvannet av Krim og en rekke sanksjoner/motsanksjoner har Putin søkt alternative allianser for å underbygge stormaktsstatus, ikke minst gjennom en mye hypet «vending mot øst» (Blakkisrud \& Wilson Rowe 2018), hvor man forsøker å trekke veksler på Russlands unike geografiske plassering med ett ben i Europa og ett i Asia. Allerede i 2013 erklærte Putin i sin årlige tale om riktets tilstand at dette var "en nasjonal oppgave for det 21 . århundre" (Putin 2013).Vendingen mot øst har både en innenriks- og en utenrikspolitisk dimensjon. Innenrikspolitisk ønsker Moskva å løfte opp den tynt befolkede, men strategisk viktige og ressursrike regionen Russisk Fjerne Østen (områdene øst for Bajkal-sjøen). Utenrikspolitisk ønsker man å komme i tettere dialog med de fremvoksende økonomiene i Sørøst-Asia som et alternativ til Vesten.

Dimensjonerende her er forholdet til Kina. Beijing blir sett som en avgjørende spiller i forsøket på å balansere det Putin oppfatter som amerikansk unilateralisme. 
Putin har møtt Xi Jinping hyppigere enn noen annen internasjonal statsleder, og de to omtaler optimistisk forholdet mellom Russland og Kina som et «strategisk partnerskap». Det økonomiske samkvemmet har økt kraftig de siste årene, og Kina er i dag Russlands viktigste handelspartner.

Samtidig er det flere skjær i sjøen - det er for eksempel ikke nødvendigvis lett for Putin og Kreml å tilpasse seg den endrede maktdynamikken hvor tidligere juniorpartner Kina nå har blitt en økonomisk storebror. Til tross for felles militærøvelser og til dels sammenfallende trusselvurderinger er det heller ingenting som tyder på at samarbeidet mellom de to innenfor Shanghai Cooperation Organisation vil utvikle seg til en formell militærallianse (Lanteigne 2018).

\section{Hvor tar Putin Russland videre?}

Putins nåværende seksårsperiode løper til 2024. Deretter må Putin, som da har sittet et kvart århundre ved makten, i henhold til grunnloven tre tilbake. Hva har Putin oppnådd? Hva vil være Putins viktigste bidrag til utenrikspolitikken de neste seks årene? Og ikke minst: Hvordan tenker Putin å trygge arven?

Det er lett å glemme i dag i hvilken forfatning og posisjon Russland var da Putin tok over roret - en fallert stormakt i full oppløsning som først og fremst hadde beholdt en plass ved internasjonale forhandlingsbord som et nikk til fordums storhet og Jeltsins rolle i oppløsningen av Sovjetunionen. Putin har spilt en sentral rolle i Russlands gradvise tilbakekomst som en regional stormakt med globale ambisjoner. Men selv om Putin langs mange parametere har lykkes i prosjektet med å gjenreise Russland, står utfordringene fortsatt i kø.

I foregående periode har Putin først og fremst vært opptatt med å posisjonere og reposisjonere - Russland på den internasjonale arena. Dette har gitt vann på mølla til de som ser på Putin som eksponent for en aggressiv, ekspansjonistisk politikk og tilløp til en demonisering av Putin i vestlige medier. Fra Moskva og Putins kontor ser verden annerledes ut: Vesten forsøker å holde Russland nede og nekte landet dets «rettmessige» posisjon som stormakt.

Vi må forvente at stormaktsambisjonen fortsatt vil være definerende for Putins politikk også i den inneværende perioden. Samtidig er det mye som tyder på at han i de neste seks årene i langt større grad vil være nødt til å vende blikket innover. Usikkerheten knyttet til arverekkefølgen - hvem Putin vil utpeke og hvordan man skal sikre en myk overgang til en ny leder - vil gradvis bli en altoverskyggende prioritet for Kreml. Det betyr at Putin i større grad vil måtte fokusere på hjemlig opinion de neste årene. Skal Putin-regimet overleve Putin selv, må han nå vende tilbake til utgangspunktet: Ved tiltredelsen i 1999 erkjente Putin at stormaktstatus ikke lenger kunne hvile på kjernefysisk avskrekkingspotensial alene, man måtte ha eget hus i skikk og et solid økonomisk fundament (Putin 1999). Så gjenstår det å se om Putin er i stand til å gjennomføre nok et politisk hamskifte og ta de nødvendige grep som skal til for å kunne sikre regimets overlevelse - og å konsolidere Russland som en stormakt av det 21 . århundre. 


\section{Om forfatteren}

Helge Blakkisrud er seniorforsker og leder for Forskningsgruppen for Russland, Asia og internasjonal handel ved Norsk Utenrikspolitisk Institutt. Han har vært gjesteforeleser ved OSSE-akademiet i Bisjkek, Kirgisistan, siden 2008. I 2009-2010 var han Fulbright Visiting Fellow ved UC Berkeley. Blakkisrud har forsket på russisk innenrikspolitikk, herunder utviklingen av regionalpolitikk og sentrum-periferi relasjoner. I tillegg jobber han med nasjonsbyggingsproblematikk og nasjonalisme. Han har vært redaktør for Nordisk Østforum siden 1994.

\section{Litteraturliste}

Applebaum, Anne (2013) «Putinism: The Ideology», Strategic Update 13.02.2013. London: LSE.

Blakkisrud, Helge (2008) «Et Russland i endring» i Even Lange, Helge Pharo \& Øyvind Østerud (red.) Vendepunkter i norsk utenrikspolitikk: Nye internasjonale vilkår etter den kalde krigen. Oslo: Unipub (209-258).

Blakkisrud, Helge \& Elana Wilson Rowe (red.) (2018) Russia's Turn to the East: Domestic Priorities and Regional Cooperation. Palgrave.

Busygina, Irina (2018) «Russian Foreign Policy as an Instrument for Domestic Mobilization», NUPI Policy Brief 2/2018. Oslo: NUPI.

Charap, Samuel (2004) «The Petersburg Experience: Putin's Political Career and Russian Foreign Policy», Problems of Post-Communism, 51 (1): 55-62.

Dyson, Stephen Benedict (2001) «Drawing Policy Implications from the 'Operational Code' of a 'New' Political Actor: Russian President Vladimir Putin», Policy Sciences, 34 (3/4): 329-346.

Hill, Fiona \& Clifford Gaddy (2013) Mr. Putin: Operative in the Kremlin. Washington, DC: Brookings Institution Press.

Kissinger, Henry A. (2014) «To Settle the Ukraine Crisis, Start at the End» The Washington Post 05.03.2014.

Lanteigne, Marc (2018) "Russia China and the Shanghai Cooperation Organization: Diverging Security Interests and the 'Crimea Effect'» i Helge Blakkisrud \& Elana Wilson Rowe (red.) Russia's Turn to the East: Domestic Priorities and Regional Cooperation. Palgrave (199-138).

Ledeneva, Alena V. (2006) How Russia Really Works: The Informal Practices That Shaped Post-Soviet Politics and Business. Ithaca, NY: Cornell University Press.

Levada (2018) «Putin’s Approval Rating». Tilgjengelig på http://www.levada.ru/en/. Lesedato 13.08.2018.

Lo, Bobo (2003) Vladimir Putin and the Evolution of Russian Foreign Policy. London: Royal Institute of International Affairs.

Lo, Bobo (2006) «Evolution of Regression? Russian Foreign Policy in Putin's Second Term» i Helge Blakkisrud (red.) Towards a Post-Putin Russia. Oslo: NUPI (57-77).

Lo, Bobo (2018) «Chutzpah and Realism: Vladimir Putin and the Making of Russian Foreign Policy», Russie. Nei.Visions 108. Paris: IFRI.

Mankoff, Jeffrey (2014) «Russia's Latest Land Grab: How Putin Won Crimea and Lost Ukraine», Foreign Affairs, 93 (3): 60-68.

Putin, Vladimir (1999) «Rossija na rubezje tysjatsjeletij» Nezavisimaja gazeta 30.12.1999. Tilgjengelig på www. ng.ru/politics/1999-12-30/4_millenium.html. Lesedato 25.07.2018.

Putin, Vladimir (2005) «Poslanie Prezidenta Federal'nomu Sobraniju» Kremlin.ru 25.04.2005. Tilgjengelig på http://kremlin.ru/events/president/transcripts/22931. Lesedato 12.08.2018.

Putin, Vladimir (2013) «Poslanie Prezidenta Federal'nomu Sobraniju» Kremlin.ru 12.12.2013. Tilgjengelig på http://kremlin.ru/events/president/news/19825. Lesedato 04.08.2018.

Rogov, Kirill (2018) «Public opinion in Putin's Russia. The public sphere, opinion climate and 'authoritarian bias'" NUPI Working Paper 878. Oslo: NUPI.

Sakwa, Richard (2008) «Putin's Leadership: Character and Consequences», Europe-Asia Studies, 60 (6): $879-897$.

Sakwa, Richard (2010) «The Dual State», Post-Soviet Affairs, 26 (3): 185-206.

Stent, Angela (2015) The Limits of Partnership: U.S.-Russian Relations in the Twenty-First Century. Princeton, NJ: Princeton University Press.

Walt, Stephen M. (2015) «Who Is a Better Strategist: Obama or Putin?» Foreign Policy 09.10.2015. Tilgjengelig på https://foreignpolicy.com/2015/10/09/who-is-a-better-strategist-obama-or-putin. Lesedato 05.10.2018.

Zygar', Mikhail (2016) Vsja kremlevskaja rat': kratkaja istorija sovremennoj Rossii. Moskva: Intellekual'naja literatura. 